\title{
Association of body mass index with the functional fitness of elderly women attending a physical activity program
}

\author{
Gislaine Cristina Vagetti \\ Valdomiro de Oliveira² \\ Michael Pereira Silva² \\ Ana Beatriz Paćifico ${ }^{2}$ \\ Tiago Rocha Alves Costa ${ }^{2}$ \\ Wagner de Campos $^{2}$
}

Abstract

Objective: to investigate the association between body mass index (BMI) and functional fitness levels linked to the Elderly in Movement Program of the city of Curitiba, in the state of Paraná, Brazil. Methods: The study is characterized as correlational and crosssectional. The sample consisted of 1,806 elderly female participants of the Elderly in Movement Program. The short version of the IPAQ was used to evaluate participation in physical activities; body weight $(\mathrm{kg})$ and height $(\mathrm{m})$ were measured to calculate BMI $\left(\mathrm{kg} / \mathrm{m}^{2}\right)$, while the motor tests proposed in the Senior Fitness Test were used to evaluate the functional fitness of the elderly women. Descriptive statistics, the chi-squared test and binary logistic regression were used for data analysis. Results: The results showed that $24.0 \%$ of the sample exhibited eutrophic nutritional status, $42.9 \%$ were overweight and $33.1 \%$ were obese. The elderly women classified as overweight and obese had lower functional fitness scores, based on the rating of Rikli and Jones, while the elderly women classified as eutrophic exhibited levels within the normal range. Obese elderly women were more likely to have low scores in the following functional fitness tests: Walk for 6 minutes, Chair Stand, Chair Sit and Reach, Back Scratch and 8-Foot Up and Go. Conclusion: The study indicated an association between, BMI and functional fitness in the elderly women participating in the program, where the majority of elderly women classified as obese exhibited low fitness in all tests.

\footnotetext{
Universidade Estadual do Paraná (UNESPAR), Campus II, Colegiado de Musicoterapia. Curitiba, PR, Brasil.

2 Universidade Federal do Paraná (UFPR), Programa de Pós-Graduação em Educação Física. Curitiba, PR, Brasil. 


\section{INTRODUCTION}

Due to the rapid increase in the number of elderly people around the world, the maintenance of the health and physical independence of such individuals has become essential to promote healthy aging, considering that the alterations that arise from this natural, inevitable and irreversible process can be prejudicial to one's physical health ${ }^{1,2}$.

Even in the absence of any given pathology, structural and functional alterations occur due to the natural aging process which can negatively influence the functional fitness of the elderly individual ${ }^{3}$. Among the alterations that are associated with aging, reductions in bone and muscle mass, flexibility and exercise and vital capacities are the most notable ${ }^{4}$.

In addition to the alterations mentioned above, literature shows that the global elderly population is not exercising sufficiently $y^{3,5}$ and the prevalence of obesity is increasing ${ }^{6}$, which negatively affects the functional fitness of these individuals ${ }^{7,8}$.

According to literature, functional fitness is the capacity an individual has to complete their daily activities independently, in a manner that is safe and without excessive expense of energy ${ }^{5}$. Due to the alterations that arise from the aging process, a decrease in functional fitness has occurred within the global elderly population ${ }^{5,8-10}$.

Among the various factors that may negatively influence one's functional fitness, the Body Mass Index (BMI) parameter should be noted. This is the relationship between the body mass and height of the individual $1^{5}$, and is also directly associated with the accumulation of body fat within a certain age range ${ }^{11}$. As a rule of thumb, as a person becomes older, their height decreases and their weight increases up to 70 years of age, while after this age, body weight tends to decrease $e^{3,12}$.

In a study by Davison et al. ${ }^{11}$, in which 2917 individuals aged at least 70 years participated, it was noted that women with a BMI of greater than or equal to $30 \mathrm{Kg} / \mathrm{m}^{2}$ were twice as likely to suffer from functional limitations.

In order to compensate for the negative effects of the natural aging process on functional fitness and increases in BMI, literature recommends that elderly individuals should engage in regular physical activity, due to the benefits it provides ${ }^{3,8,12-15}$. Being physically active during this period of life is directly associated with greater quality of life and increased independence in performing daily activities ${ }^{8,10,16}$, in addition to the positive effects that such activity has on $\mathrm{BMI}^{17}$.

In light of this evidence, an investigation of the association between BMI and functional fitness among elderly women is of great importance, since gaining an understanding of the various factors that contribute to the decrease in functional fitness during old age may help to develop efficacious preventive strategies that can contribute positively to successful aging.

Hence, the objective of the present study was to investigate the association between BMI and the levels of functional fitness in elderly female patients enrolled in the Idoso em Movimento (Elderly Person in Movement) program in the city of Curitiba, in the state of Paraná, Brazil.

\section{METHOD}

The study was undertaken with elderly female participants from the Idoso em Movimento program under the auspices of the Secretaria Municipal de Esporte e Lazer (the Municipal Secretariat of Sport and Leisure) in 32 care centers within the nine administrative districts of the city of Curitiba, Paraná, Brazil. The sample of the study was probabilistic and was obtained via the technique of randomly selecting a group proportional to the size of each district. In order to calculate the size of the sample required for this study, the following statistical parameters were taken into account: a) a population of 4,346 elderly female participants of the program from the nine administrative districts in Curitiba (only 54 men were enrolled in the program, explaining why only women were chosen); b) a prevalence of low quality of life (QL) of 50\%, taking into account maximum variance; c) a confidence level of $95 \%$ $(s d=1.96) ; d)$ a sampling error of 3 percentage points; e) a design effect of 2.0 to correct for the biases of sampling selection by group; and f) a margin of $30 \%$ for possible losses and refusals. Therefore, based on 
the sampling calculation, the sample of this study was estimated at 1,886 elderly women.

With the aim of complying with the criteria adopted for selecting the sample, and to reduce possible intervening variables, some criteria were applied to exclude certain elderly female participants were younger than 60 years old and suffered from severe musculoskeletal, neurological and cardiac disorders that could compromise or could become a limiting factor for the completion of functional fitness tests were not included.

Of the 1,895 elderly women that participated in the data collection process, 89 (4.7\%) were excluded for not having completed all the evaluations included in this study (questionnaires and the anthropometric evaluations). No refusals to participate in the study were registered. Therefore, the final sample of the study consisted of 1,806 elderly women, representing $95.3 \%$ of the elderly women evaluated.

Data collection took place between February and June 2011. The questionnaires were applied during individual interviews due to possible reading difficulties on the part of the participants, including visual deficiencies or illiteracy among the elderly women. The interview, anthropometric evaluation (weight and height measurements) and the functional fitness tests were administered by professionals that were associated with the Centro de Pesquisa em Exercício e Esporte (the Exercise and Sports Research Center) of the Universidade Federal do Paraná (the Federal University of Paraná). These evaluators participated in training sessions that consisted of theoretical explanations and practical simulations for data collection, in addition to being involved in a pilot study that was carried out under the same conditions as those of the principal study.

The present study evaluated, via questionnaire ${ }^{18}$ sociodemographic variables (skin color/ethnicity, income bracket, academic background, employment status and marital status) and variables related to clinical and health conditions (self-reported health issues, blood pressure, quantity of medications taken and perception of health); information related to age range (60-64; 65-69; 70-74; 75-79; $\geq 80$ years); skin color/ethnicity (white (Caucasian), brown (mixedrace)/black (Afro-Brazilian), and others); marital

status (single, married, separated and widowed); employment status (retired, pensioner, unemployed/ homemaker); and academic background (incomplete elementary school, complete elementary school, high school graduate and university graduate). Income bracket was evaluated based on the questionnaire developed by the Associação Brasileira de Empresas de Pesquisa (the Brazilian Association of Research Companies) (ABEP) ${ }^{19}$. This instrument aims to estimate the purchasing power of the family and the academic background of the head of the household, generating a score that estimates income brackets that range from A (highest income bracket) to $\mathrm{E}$ (lowest income bracket). The income brackets were grouped into upper $(\mathrm{A}+\mathrm{B})$, middle $(\mathrm{C})$ and lower class $(\mathrm{D}+\mathrm{E})$.

Other clinical and health conditions were conveyed by the elderly women participants during the interview, based on the following questions: Do you suffer from a health condition? (no and yes); Do you take any medication? (none, one medication, two medications, three or more medications).

The amount of time that the elderly female participant engaged in physical exercise per week (week before data collection), based on walking and moderate to intense physical exercise, was estimated based on the short version of the International Physical Activity Questionnaire (IPAQ), which has been previously validated for the Brazilian population ${ }^{12}$. The elderly female participants were classified as $\leq 149$ $\mathrm{min} /$ week; 150-299 $\mathrm{min} /$ week, and $\geq 300 \mathrm{~min} /$ week.

Body mass (kg) and height (m) were measured in order to calculate the BMI $\left(\mathrm{kg} / \mathrm{m}^{2}\right)$, and individuals were categorized into categories based on this index. The body masses of participants were obtained by means of a portable digital scale (make: Wiso; model: W801), which had a variability of $0.1 \mathrm{~kg}$ and a capacity of up to $180 \mathrm{~kg}$. The participants were weighed only once in the standard anatomical position, without shoes and wearing light clothing. The height of participants was obtained using a portable stadiometer (make: WCS; model: Compact) that measured a range of between 0 and $220 \mathrm{~cm}$. Height was measured while the participants held their breath. Participants did not wear shoes, maintained their heels together in the standard anatomical position, and were instructed to position their heads according to the Frankfurt plane. After these evaluations, 
the data were used to calculate BMI, which was classified according to the following World Health Organization parameters (WHO, 2000): eutrophic $\left(18.5-24.9 \mathrm{~kg} / \mathrm{m}^{2}\right)$, overweight $\left(25-29.9 \mathrm{~kg} / \mathrm{m}^{2}\right)$ and obese $\left(\geq 30 \mathrm{~kg} / \mathrm{m}^{2}\right)$.

The motor tests proposed in the Senior Fitness Test were used to evaluate the functional fitness of the

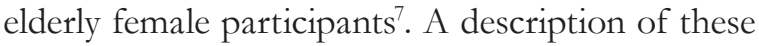
tests is presented in Table 1. Each of the tests were completed in the form of a circuit in an attempt to minimize the effects of localized fatigue, and the performances of the participants in said tests were recorded on individual cards. Before beginning the tests, each participant warmed up for 10 minutes. The recovery interval between the tests lasted approximately 2 minutes. To familiarize participants with the battery of tests, some time was set aside for explanation and experimentation ${ }^{7}$. The classification of the functional fitness of participants was undertaken in accordance with the Rikli and Jones benchmarks ${ }^{7}$ : Low: $<50$ percentile; Adequate: $\geq 50$ percentile.

Table 1. Description of the tests composing the Senior Fitness Test (SFT) used to identify the categories of body mass index and the level of functional fitness among elderly female participants. Curitiba, Paraná, 2011.

\begin{tabular}{|c|c|c|}
\hline Name & Purpose & Description \\
\hline Body mass index & Evaluate body mass index & $\begin{array}{l}\text { Ratio of the weight and height }\left(\mathrm{kg} / \mathrm{m}^{2}\right) \text {; with normal weight, } \\
\text { overweight and obese classified into the following categories, } \\
\text { respectively: } 18.5-24.9 \mathrm{~km} / \mathrm{m}^{2}, 25-29.9 \mathrm{~kg} / \mathrm{m}^{2} \text { and } \geq 30 \mathrm{~kg} / \\
\mathrm{m}^{2} \text {, in accordance with WHO standards }(2000) \text {. }\end{array}$ \\
\hline 6 minute walk & $\begin{array}{l}\text { Evaluate cardiovascular } \\
\text { resistance }\end{array}$ & $\begin{array}{l}\text { Maximum distance (in meters) that the participant walked } \\
\text { during } 6 \text { minutes within a rectangular, } 50 \text {-meter circuit. }\end{array}$ \\
\hline Arm curl & $\begin{array}{l}\text { Evaluate strength of the upper } \\
\text { limbs }\end{array}$ & $\begin{array}{l}\text { Number of repetitions of arm curls executed during } 30 \mathrm{~s} \\
\text { while holding a } 2.5 \mathrm{~kg} \text { dumbbell. }\end{array}$ \\
\hline Chair stand & $\begin{array}{l}\text { Evaluate strength of the lower } \\
\text { limbs }\end{array}$ & $\begin{array}{l}\text { Number of repetitions where the participant can stand up } \\
\text { and return to their initial (seated) position in } 30 \text { s. }\end{array}$ \\
\hline Chair sit and reach & $\begin{array}{l}\text { Evaluate the flexibility of the } \\
\text { lower limbs }\end{array}$ & $\begin{array}{l}\text { With the participant in seated position with legs extended, } \\
\text { measure the maximum extension distance }(\mathrm{cm}) \text { while } \\
\text { lowering the torso in the direction of the feet. }\end{array}$ \\
\hline Back scratch & $\begin{array}{l}\text { Evaluate the flexibility of the } \\
\text { upper limbs }\end{array}$ & $\begin{array}{l}\text { The participant must position their dominant hand over the } \\
\text { same shoulder and the other hand below and behind the } \\
\text { back in an attempt to link both hands; the distance between } \\
\text { the hands is then measured. }\end{array}$ \\
\hline 8 foot up and go & $\begin{array}{l}\text { Evaluate the participants' } \\
\text { physical mobility (speed, agility } \\
\text { and dynamic balance) }\end{array}$ & $\begin{array}{l}\text { Amount of time that the participant takes to walk } 2.44 \mathrm{~m} \\
\text { from the seated position and return to the starting position. }\end{array}$ \\
\hline
\end{tabular}

Descriptive analysis was conducted via measurements of central tendency and dispersal (average and standard deviation), as well as measurements of absolute and relative frequency. The chi-squared test was used to verify the significant differences between functional fitness and the categories of nutritional status.

The association between nutritional status and the components of functional fitness was investigated using binary logistic regression with the aim of identifying the odds ratio with a $95 \%$ confidence interval. The age range and the amount of time the participant engaged in moderate to intense physical activity were used as control variables. A $p$ value of $<0.05$ was used as the significance level in each of the analyses.

The Research Ethics Committee of the Department of Sciences and Health of the Federal University of Paraná approved this study (registration No. 1040.165.10.11). Each of the elderly female participants that completed the study signed an Informed Consent Form. 


\section{RESULTS}

The average age of the participants in the final sample was $68.7( \pm 6.3)$ years, and varied between 60.0 and 84.92 years. The greatest proportions of participants were classified within the following categories: age range of between 60 and 64 years (35\%), Caucasian race/ethnicity (80.7\%), level C income bracket (57.5\%), completed elementary school (44.6\%), retired (58.8\%) and widowed (40.4\%). Approximately four in every ten elderly female participants engaged in between 150 and 299 minutes of moderate to intense exercise per week, whereas only $6.9 \%$ of these participants reported that they exercised in such a manner for 300 or more minutes per week (Table 2).

Table 3 shows that only $24.0 \%$ of the sample had a BMI classification of eutrophic, whereas $42.9 \%$ and $33.1 \%$ of the participants were overweight and obese, respectively. Regarding functional fitness, the majority of the sample was classified as adequate in the majority of the tests: Walk. for 6 minutes (51.4\%), Arm curl (55.6\%), Chair stand (60.9\%), Chair sit and reach (53.2\%), Back scratch (51.1\%) and 8 foot up and go $(50.2 \%)$.

Table 2. Sociodemographic characteristics and physical activity levels of the elderly female participants. Curitiba, Paraná, 2011.

\begin{tabular}{|c|c|}
\hline Variables & $\mathrm{N}(\%)$ \\
\hline \multicolumn{2}{|l|}{ Age Group (years) } \\
\hline $60-64$ & $624(35.0)$ \\
\hline $65-69$ & $432(24.2)$ \\
\hline $70-74$ & $409(22.9)$ \\
\hline $75-79$ & $196(11.0)$ \\
\hline $80-84$ & $122(6.8)$ \\
\hline \multicolumn{2}{|l|}{ Race/ethnicity } \\
\hline Caucasian & $1438(80.7)$ \\
\hline Brown/black (mixed race/Afro-Brazilian) & $214(12.0)$ \\
\hline Others & $131(7.3)$ \\
\hline \multicolumn{2}{|l|}{ Income Bracket } \\
\hline $\mathrm{A}+\mathrm{B}$ (highest income bracket) & $588(33.0)$ \\
\hline $\mathrm{C}$ & $1026(57.5)$ \\
\hline $\mathrm{D}+\mathrm{E}$ (lowest income bracket) & $169(9.5)$ \\
\hline \multicolumn{2}{|l|}{ Academic Background } \\
\hline Elementary school (incomplete) & $573(32.1)$ \\
\hline Elementary school (completed) & $796(44.6)$ \\
\hline High school (graduated) & $267(15.0)$ \\
\hline University (graduated) & $147(8.2)$ \\
\hline \multicolumn{2}{|l|}{ Employment Status } \\
\hline Retired & $1047(58.8)$ \\
\hline Pensioner & $358(20.1)$ \\
\hline Unemployed/homemaker & $378(21.2)$ \\
\hline \multicolumn{2}{|l|}{ Marital Status } \\
\hline Single & $141(7.9)$ \\
\hline Married & $726(40.7)$ \\
\hline Separated & $196(11.0)$ \\
\hline Widowed & $720(40.4)$ \\
\hline
\end{tabular}


Continued from Table 2

\begin{tabular}{ll}
\hline Variables & $\mathrm{N}(\%)$ \\
\hline Health Issues & $389(21.8)$ \\
No & $1394(78.2)$ \\
Yes & \\
Quantity of medications taken & $400(22.4)$ \\
None & $786(44.1)$ \\
1 & $444(24.9)$ \\
2 & $153(8.6)$ \\
3 or more & \\
\hline Moderate to intense exercise (mins/week) & $892(50.0)$ \\
$0-149$ & $768(43.1)$ \\
$150-299$ & $123(6.9)$ \\
\hline 300 & \\
\hline
\end{tabular}

Table 3. Body mass index categories and functional fitness levels in elderly female participants from Curitiba, Paraná, 2011.

\begin{tabular}{|c|c|}
\hline Variables & $\mathrm{N}(\%)$ \\
\hline \multicolumn{2}{|c|}{ Body Mass Index Categories* } \\
\hline Eutrophic & $434(24.0)$ \\
\hline Overweight & $774(42.9)$ \\
\hline Obesity & $598(33.1)$ \\
\hline \multicolumn{2}{|c|}{ Functional Fitness** } \\
\hline \multicolumn{2}{|c|}{6 minute walk } \\
\hline Low & $878(48.6)$ \\
\hline Adequate & $928(51.4)$ \\
\hline \multicolumn{2}{|l|}{ Arm curl } \\
\hline Low & $801(44.4)$ \\
\hline Adequate & $1005(55.6)$ \\
\hline \multicolumn{2}{|l|}{ Chair Stand } \\
\hline Low & $707(39.1)$ \\
\hline Adequate & $1099(60.9)$ \\
\hline \multicolumn{2}{|c|}{ Chair sit and reach } \\
\hline Low & $846(46.8)$ \\
\hline Adequate & $960(53.2)$ \\
\hline \multicolumn{2}{|l|}{ Back scratch } \\
\hline Low & $883(48.9)$ \\
\hline Adequate & $923(51.1)$ \\
\hline \multicolumn{2}{|c|}{8 foot up and go } \\
\hline Low & $899(49.8)$ \\
\hline Adequate & $907(50.2)$ \\
\hline
\end{tabular}

*Body mass index classification according to the $\mathrm{WHO}^{16}$ : Eutrophic: $<25 \mathrm{~kg} / \mathrm{m}^{2}$, Overweight: Between 25 e $29.9 \mathrm{Kg} / \mathrm{m}^{2}$ e Obesity: $\geq 30 \mathrm{Kg} / \mathrm{m}^{2}$; **The classification of functional fitness was undertaken in accordance with the Rikli and Jones benchmarks ${ }^{7}:$ Low: $<50$ percentile; Adequate: $\geq 50$ percentile. 
Table 4 shows the proportion of elderly female participants that had low or adequate fitness in the functional fitness tests according to the BMI categories. The majority of elderly female participants that were classified as being obese displayed low fitness in each of the following tests: Walk for 6 minutes (41.8\%\%), Arm curl (35.0\%), Chair stand (37.9\%), Chair
(26.3\%), Chair sit and reach (28.2\%), Back scratch (31.3\%) and 8 foot up and go $(42.0 \%)$.

The analyses of association between BMI categories and functional fitness are presented in Table 5. Obese elderly female participants were more likely to display low functional fitness in the following tests: Walk for 6 minutes (OR=2.28; CI 95\%: 1.77-2.95), Chair stand (OR=1.65; CI 95\%: 1.27-2.14), Chair sit and reach (OR=1.96; CI 95\%: 1.52-2.53), Back scratch (OR=3.78; CI 95\%: 2.90-4.93) and 8 foot up and go $(\mathrm{OR}=2.50$; CI 95\%: 1.93-3.23).

Table 4. Levels of functional fitness stratified into categories of body mass index for elderly female participants in the city of Curitiba, Paraná, 2011.

\begin{tabular}{|c|c|c|c|c|c|}
\hline \multirow[b]{2}{*}{ Functional capacity $^{*}$} & \multicolumn{5}{|c|}{ Body mass index categories } \\
\hline & Eutrophic & Overweight & Obese & $X^{2}$ & $\mathrm{p}$ \\
\hline \multicolumn{6}{|l|}{6 minute walk } \\
\hline Low & $20.4 \% 0^{\mathrm{a}}$ & $37.8 \% \%^{\mathrm{a}}$ & $41.8 \%{ }^{\mathrm{b}}$ & 58.532 & 0.000 \\
\hline Adequate & $27.5 \%{ }^{\mathrm{a}}$ & $47.6 \%{ }^{\mathrm{a}}$ & $24.9 \%{ }^{\mathrm{b}}$ & & \\
\hline \multicolumn{6}{|l|}{ Arm curl } \\
\hline Low & $26.2 \% 0^{a}$ & $38.8 \%{ }^{\mathrm{b}}$ & $35.0 \% 0^{\mathrm{a}}$ & 9.798 & 0.007 \\
\hline Adequate & $22.3 \% \%^{\mathrm{a}}$ & $46.1 \%{ }^{\mathrm{b}}$ & $31.6 \% 0^{\mathrm{a}}$ & & \\
\hline \multicolumn{6}{|l|}{ Chair Stand } \\
\hline Low & $20.5 \%{ }^{\mathrm{a}}$ & $41.6 \%{ }^{\mathrm{a}}$ & $37.9 \%{ }^{\mathrm{b}}$ & 14.502 & 0.001 \\
\hline Adequate & $26.3 \% 0^{\mathrm{a}}$ & $43.7 \% \%^{a}$ & $30.0 \% 0^{\mathrm{b}}$ & & \\
\hline \multicolumn{6}{|l|}{ Chair sit and reach } \\
\hline Low & $19.3 \% \%^{\mathrm{a}}$ & $42.1 \%{ }^{\mathrm{b}}$ & $38.7 \%{ }^{\mathrm{c}}$ & 30.009 & 0.000 \\
\hline Adequate & $28.2 \%^{\mathrm{a}}$ & $43.5 \%{ }^{\mathrm{b}}$ & $28.2 \%^{\mathrm{a}}$ & & \\
\hline \multicolumn{6}{|l|}{ Back scratch } \\
\hline Low & $16.4 \% 0^{\mathrm{a}}$ & $39.3 \%{ }^{\mathrm{b}}$ & $44.3 \%^{\mathrm{c}}$ & 111.831 & 0.000 \\
\hline Adequate & $31.3 \% \%^{\mathrm{a}}$ & $46.3 \%{ }^{\mathrm{b}}$ & $22.4 \% 0^{\mathrm{c}}$ & & \\
\hline \multicolumn{6}{|l|}{8 Foot up and go } \\
\hline Low & $19.9 \% 0^{a}$ & $38.0 \% 0^{\mathrm{a}}$ & $42.0 \%{ }^{\mathrm{b}}$ & 65.485 & 0.000 \\
\hline Adequate & $28.1 \% \%^{a}$ & $47.6 \% 0^{a}$ & $24.3 \%^{\mathrm{b}}$ & & \\
\hline
\end{tabular}

$X^{2}$ : Chi-squared test; ${ }^{*}$ Functional fitness was classified in accordance with the Rikli and Jones benchmarks ${ }^{7}$ Low: $<50$ percentile; Adequate: $\geq 50$ percentile; $\mathrm{a} / \mathrm{b} / \mathrm{c}$ : different letters denote the existence of significant statistical differences between the body mass index categories 
Table 5. Ratio of chances and 95\% confidence intervals for the association between body mass index and functional fitness in elderly female participants. Curitiba, Paraná, 2011.

\begin{tabular}{|c|c|c|c|c|c|c|}
\hline & $\begin{array}{l}6 \text { minute walk } \\
\text { (Low) }\end{array}$ & $\begin{array}{l}\text { Arm Curl } \\
\text { (Low) }\end{array}$ & $\begin{array}{l}\text { Chair Stand } \\
\text { (Low) }\end{array}$ & $\begin{array}{l}\text { Chair sit } \\
\text { and reach } \\
\text { (Low) }\end{array}$ & $\begin{array}{l}\text { Back scratch } \\
\text { (Low) }\end{array}$ & $\begin{array}{l}8 \text { Foot up } \\
\text { and go } \\
\text { (Low) }\end{array}$ \\
\hline $\begin{array}{l}\text { Body mass index } \\
\text { categories }\end{array}$ & $\begin{array}{l}\text { Odds Ratio }{ }^{a} \\
(\text { CI 95\%) }\end{array}$ & $\begin{array}{l}\text { Odds Ratio }{ }^{a} \\
(\text { CI 95\%) }\end{array}$ & $\begin{array}{l}\text { Odds Ratio }{ }^{a} \\
(\text { CI 95\%) }\end{array}$ & $\begin{array}{l}\text { Odds Ratio } \\
(\mathrm{CI} 95 \%)\end{array}$ & $\begin{array}{l}\text { Odds Ratio }^{a} \\
(\text { CI 95\%) }\end{array}$ & $\begin{array}{l}\text { Odds Ratioa } \\
\text { (CI 95\%) }\end{array}$ \\
\hline Eutrophic & 1 & 1 & 1 & 1 & 1 & 1 \\
\hline Overweight & $\begin{array}{l}1,07 \\
(0.84-1.36)\end{array}$ & $\begin{array}{l}0,71 * \\
(0.56-0.90)\end{array}$ & $\begin{array}{l}1,22 \\
(0.95-1.57)\end{array}$ & $\begin{array}{l}1,40^{*} \\
(1.10-1.79)\end{array}$ & $\begin{array}{l}1,62 * \\
(1.27-2.08)\end{array}$ & $\begin{array}{l}1,13 \\
(0.89-1.44)\end{array}$ \\
\hline Obese & $\begin{array}{l}2,28^{*} \\
(1.77-2.95)\end{array}$ & $\begin{array}{l}0,91 \\
(0.71-1.17)\end{array}$ & $\begin{array}{l}1,65^{*} \\
(1.27-2.14)\end{array}$ & $\begin{array}{l}1,96^{*} \\
(1.52-2.53)\end{array}$ & $\begin{array}{l}3,78^{*} \\
(2.90-4.93)\end{array}$ & $\begin{array}{l}2,50^{*} \\
(1.93-3.23)\end{array}$ \\
\hline
\end{tabular}

a: Adjusted by age range and level of physical activity; ${ }^{*} p<0.0$.

\section{DISCUSSION}

With the dramatic increase in the number of elderly individuals and the physical alterations that arise as a result of the natural aging process, policies that aim to maintain the physical independence of this population must be put in place ${ }^{4,17,20-23}$. Literature on this subject demonstrates that elderly individuals from younger age ranges have greater BMI values than those elderly persons that are over 70 years old $^{24}$. Some studies corroborate this by identifying that higher BMI values negatively influence the functional mobility of elderly persons $\mathrm{s}^{3,5,12}$.

The results of this study showed that a large part of the sample was overweight, with $42.9 \%$ and $33.1 \%$ of elderly female participants classified as being overweight and obese, respectively. These results corroborate a study by Leite-Cavalcanti et al. ${ }^{25}$, which found that $46.2 \%$ of the elderly in the sample were classified as being overweight, whereas $40.2 \%$ were classified as being Class I obese, in accordance with the cut-off values of the BMI system for the overall population.

The elderly female participants that were classified as being overweight in this study attained lower functional fitness scores, whereas the elderly female participants that were classified as being eutrophic obtained scores that were within the limits of normalcy for the same variable. These results corroborate the results obtained by Elias et al. ${ }^{26}$, in which 11 of 18 elderly female participants were classified as being overweight. Among the 11 elderly female participants that were classified as being overweight, 10 exhibited low arm strength and insufficient aerobic conditioning, while all elderly female participants presented low physical mobility.

A study by Piccoli et al. ${ }^{27}$ analyzed correlations between BMI and overall motor coordination and static balance among 202 elderly participants. Negative correlations were found between these variables, with a correlation of -0.423 obtained for $\mathrm{BMI}$ and overall motor coordination, and a correlation of -0.306 obtained for BMI and static balance.

In the study by Vilaça et al. ${ }^{28}$, muscular strength and walking tests were undertaken by a sample of 77 female volunteers aged between 65 and 80 years, who were recruited in community integration programs in the city of Ribeirão Preto in the state of São Paulo. The elderly female participants were divided into three groups, where group A corresponded to the elderly female participants that walked, on average, $369.7 \pm 57.6 \mathrm{~m}$ (240-428m), group B corresponded to participants that walked, on average, $450.2 \pm 12.3 \mathrm{~m}$ (433-470m), and group C corresponded to participants that walked, on average, $524 \pm 44.5(478-643 \mathrm{~m})$ in the Walk. for 6 minutes test. The elderly female participants that walked a shorter distance also had higher BMIs, a greater amount of body fat and worse physical performance, which suggests that an elevated proportion of body fat has a negative influence on functional performance, even in active elderly female participants. Such results are in keeping with the findings of the present study, where the participants from the obese group were 2.28 times more likely to present inadequate performance in the Walk. for 6 minutes test. 
In the present study, elderly female participants that were classified as obese demonstrated low functional fitness in the Chair stand test, which conflicts with the study completed by Barbosa et al. ${ }^{29}$ which aimed to identify an association between the nutritional status of elderly participants and their motor performance. In the study by Barbosa et al. ${ }^{29}$, participants were required to complete five repetitions of the Chair stand test; no associations between BMI and this test were encountered.

A study by Mazo et al. ${ }^{7}$ aimed to investigate the relationship between the Overall Functional Fitness Index (OFFI) and the BMI of 52 elderly female participants who engaged in regular exercise. Of the 52 elderly female participants, only five $(9.6 \%)$ of them were classified as having a good OFFI. Of the five elderly female participants with a good OFFI, two were overweight. Of the 47 elderly female participants $(90.4 \%)$ that were classified as having a poor OFFI, $43(95.6 \%)$ were classified as being overweight. In order to confirm the reliability of the results of the Mazo et al. study ${ }^{7}$, Fisher's Exact Test was applied. The test produced a value of 0.014 , which confirmed the significance of the results of Mazo et al., in which there was a tendency of $95.6 \%$ of the elderly female participants classified as overweight according to $\mathrm{BMI}$ to have a poor OFFI, thus producing an inverse relationship between BMI and physical fitness among the elderly female participants.

Rech et al..$^{30}$ reached the same conclusions in a study which verified the association between functional fitness and being overweight among 394 women with an average age of 69.4 years. The results showed that overweight elderly female participants had lower OFFI ratings $(p<0.001)$. In addition, the overweight elderly female participants were 5.07 (CI 95\% =3.12-7.14) times more likely to have low functional fitness than eutrophic participants, resulting in an inverse relationship between BMI and functional fitness in accordance with OFFI.

Danielewicz; Barbosa and Duca ${ }^{31}$, by means of a transverse epidemiological study of 477 elderly participants of both genders, aged from 60 to 100 years old, showed that underweight $(\mathrm{BMI}<22 \mathrm{~kg} /$ $\mathrm{m} 2$ ) was associated with functional limitation and excess weight (BMI $>27 \mathrm{~kg} / \mathrm{m} 2)$ was associated with deficiencies in the Activities of Daily Living Scale.
Moreover, these associations were independent of gender, age, academic background, occupation, purchasing power and cognitive state.

Soares et al..$^{32}$ completed a study which aimed to investigate the association between nutritional status and motor ability performance in elderly individuals. Their results also corroborate the results of the present study, in which an inverse association was found between elderly individuals classified as obese and motor skill performance $(p<0.005)$. Obese elderly individuals needed more time to execute the same activities than eutrophic elderly individuals. The authors of the study affirm that various factors can influence the association between obesity and poor performance in motor tests, such as, for example, a greater risk of an elderly individual suffering from osteoarthritis in the knees (and such condition being of greater severity) and an excess of body fat, which increases overloading in the body, making movement more difficult and increasing stress on the joints.

Moreira et al. ${ }^{33}$ presented results that supplement the results of the present study. By means of a longitudinal study, performed on a sample of 103 elderly participants aged 67 to 92 , who were residents of a determined Brazilian community, the authors concluded that from 2008 to 2010, the elderly participants exhibited reduced lean muscle mass, increases in obesity rates and a reduction in physical functioning due to increasing age. In addition to identifying risk factors such as hypertension, it was noted that arthritis and depression can be identified and treated, helping to prevent functional decline in the elderly.

The results of this study are subject to limitations. The first is related to the fact that the sample was selected from elderly care centers, making it impossible to extrapolate the results to the populations of Curitiba or Brazil as a whole. The utilization of a cross-sectional study to indicate associations between the variables also represents a limitation of the present study, since the possibility of achieving reverse causality is a characteristic that is inherent to the cross-sectional study experimental design. The limitations mentioned suggest that caution should be adopted when attempting to extrapolate the results of the present study. 


\section{CONCLUSIONS}

The present study indicated an association between BMI and the functional fitness of elderly women enrolled in the Idoso em Movimento program in the city of Curitiba, Paraná, Brazil. The results showed that the majority of the elderly female participants that were evaluated were either overweight or obese. The majority of individuals classified as obese exhibited low fitness in each of the tests that were completed. It was shown that a greater proportion of elderly female participants classified as eutrophic displayed adequate functional fitness when executing the following tests: Walk for 6 minutes, Chair stand, Chair sit and reach, Back scratch, and 8 foot up and go. The analyses of the variable categories of BMI associated with functional fitness revealed that obese elderly female participants were more likely to have low functional fitness for the following tests: Walk for 6 minutes, Chair stand, Chair sit and reach, Back scratch and 8 foot up and go.

The present study indicates that the BMI categories of the elderly female participants from the program are associated with functional fitness. This emphasizes the importance of controlling the BMI of elderly persons, as it can interfere with the execution of activities that involve functional fitness, which are of fundamental importance to the dayto-day life of elderly individuals, ensuring they are capable of carrying out their daily activities through the use of muscular exertion, physical conditioning, flexibility, agility and balance.

\section{REFERENCES}

1. Instituto Brasileiro de Geografia e Estatística. Censo Demográfico. Rio de Janeiro: IBGE; 2010.

2. Olsson IN, Runnamo R, Engfeldt P. Medication quality and quality of life in the elderly, a cohort study. Health Qual Life Outcomes. 2011;9(1):95.

3. Chodzko-Zajko W, Proctor DN, Fiatarone SMA, Minson CT, Nigg GR, Salem GJ, et al. Exercise and physical activity for older adults. Med Sci Sports Exerc. 2009;41(7):1510-30.

4. Chou CH, Hwang CL, Wu YT. Effect of exercise on physical function, daily living activities, and quality of life in the frail older adults: a meta-analysis. Arch Phys Med Rehabil. 2012;93(2):237-44.

5. Rikli R, Jones J. Development and validation of a Functional Fitness Test for community-residing older adults. J Aging Phys Act. 1999;7:129-61.

6. Cabrera MAS, Jacob FIlho W. Obesidade em idosos: prevalência, distribuição e associação com hábitos e co-morbidades. Arq Bras Endocrinol Metab. 2001;45(5):494-501.

7. Mazo GZ, Kulkamp W, Lyra VB, Prado APM. Aptidão Funcional Geral e índice de massa corporal de idosas praticantes de atividade física. Rev Bras Cineantropom Desempenho Hum. 2006;8(4):46-51.

8. Milanović Z, Pantelić S, Trajković N, Sporis G, Kostić, James N. Age-related decrease in physical activity and functional fitness among elderly men and women. Clin interv aging. 2013;8:549-56.
9. Gerage AM, Januário RSB, Nascimento MA, Pina FLC, Cyrino ES. Impact of 12 weeks of resistance training on physical and functional fitness in elderly women. Rev Bras Cineantropom Desempenho Hum. 2013;15(2):145-54.

10. Vagetti GC, Barbosa Filho VC, Oliveira V, Mazzardo O, Moreira NB, Campos W. Functional fitness in older women from southern brazil: normative scores and comparison with different countries. Rev Bras Cineantropom Desempenho Hum. 2015;4(17):472-84.

11. Davison KK, Ford ES, Cogswell ME, Dietz WA. Percentage of body fat and body mass index are associated with mobility limitations in people aged 70 and older from NHANES III. J Am Geriatric Soc. 2002;50(11):1802-9.

12. Matsudo S, Araujo T, Matsudo V, Andrade D, Andrade D, Oliveira LC, et al. Questionário internacional de atividade física (IPAQ): estudo de validade e reprodutibilidade no brasil. Rev Bras Ativ Fis Sáude. 2001;6(2):5-18.

13. Garber CE, Blissmer B, Deschenes NR, Franklin BA, Lamonte MJ, Lee IM, et al. American College of Sports Medicine position stand. Quantity and quality of exercise for developing and maintaining cardiorespiratory, musculoskeletal, and neuromotor fitness in apparently healthy adults: guidance for prescribing exercise. Med Sci Sports Exerc. 2011;43(7):1334-59. 
14. Koeneman MA, Verheijden MW, Chinapaw MJM, Hopman-Rock M. Determinants of physical activity and exercise in healthy older adults: a systematic review. Int J Behav Nutr Phys Act. 2011;8(142):1-15.

15. Ueno DT, Gobbi S, Teixeira CVL, Sebastião E, Prado AKG, Costa JLR, et al. Efeitos de três modalidades de atividade física na capacidade funcional de idosos. Rev Bras Educ Fís Esporte. 2012;26(2):273-28.

16. World Health Organization. Global recommendations on physical activity for health. Geneva: WHO; 2010.

17. Gudlaugsson J, Gudnason V, Aspelund T, Siggeirsdottir K, Olafsdottir AS, Jonsson PV, et al. Effects of a 6-month multimodal training intervention on retention of functional fitness in older adults: a randomized-controlled cross-over design. Int J Behav Nutr Phys Act. 2012;9(1):1-11.

18. Mazo G. Atividade física e qualidade de vida de mulheres idosas (tese). Porto: Universidade do Porto, Faculdade de Ciências do Desporto e de Educação Física; 2003.

19. Associação Brasileira das Empresas de Pesquisa. Critério de classificação econômica Brasil. São Paulo: ABEP; 2015.

20. Costa EC, Nakatani AYK, Bachion MM. Capacidade de idosos da comunidade para desenvolver atividades de vida diária e atividades instrumentais de vida diária. Acta Paul Enferm. 2006;19(1):43-8.

21. Costa Rosa ET, Benício MHD, Latorre MRDO, Ramos LR. Fatores determinantes da capacidade funcional entre idosos. Rev Saúde Pública. 2003;37(1):40-8.

22. Nascimento CMC, Ayan C, Cancela JM, Pereira JR, Andrade LP, Garuffi M, et al. Exercícios físicos generalizados, capacidade funcional e sintomas depressivos em idosos brasileiros. Rev Bras Cineantropom Desempenho Hum. 2013;15(4):486-97.

23. Tavares DMS, Dias FA. Functional capactiy, morbidities and quality of life. Texto \& Contexto Enferm. 2012;21(1):112-20.

24. Martins TI, Meneguci J, Damião R. Pontos de corte do índice de massa corporal para classificar o estado nutricional em idosos. REFACS. 2014;3(2):78-87.
25. Leite-Cavalcanti C, Rodrigues-Gonçalves MC, RiosAsciutti LS, Cavalcanti A. Prevalência de doenças crônicas e estado nutricional em um grupo de idosos brasileiros. Rev Salud Pública. 2009;11(6):865-77.

26. Elias RGM, Gonçalves ECA, Moraes ACF, Moreira $\mathrm{CF}$, Fernandes CAM, et al. Aptidão física funcional de idosos praticantes de hidroginástica. Rev Bras Geriatr Gerontol. 2012;15(1):79-86.

27. Piccoli JCJ, Quevedo DM, Santos GA, Ferrareze ME, Gluher A. Coordenação global, equilíbrio, índice de massa corporal e nível de atividade física: um estudo correlacional em idosos de Ivoti, RS, Brasil. Rev Bras Geriatr Gerontol. 2012;15(2):209-21.

28. Vilaça KHC, Alves NMC, Carneiro JAO, Ferrioli E, Lima NKC, Morigutti JC. Body composition, muscle strength and quality of active elderly women according to the distance covered in the 6-minute walk test. Braz J Phys Ther. 2013;17(3):289-96.

29. Barbosa AR, Souza JMP, Lebrão ML, Marucci MFN. Estado nutricional e desempenho motor de idosos de São Paulo. Rev Assoc Med Bras. 2007;53(1):75-9.

30. Rech CR, Cruz JLS, Araujo EDS, Kalinowski FG, Dellagrana RA. Associação entre aptidão funcional e excesso de peso em mulheres idosas. Motricidade. 2010;6(2)47-53.

31. Danielewicz AL, Barbosa AR, Duca GFD. Nutritional status, physical performance and functional capacity in an elderly population in southern Brazil. Rev Assoc Med Bras. 2014;60(3):242-8.

32. Soares LDA, Campos LDA, Campos FACS, Araújo MGR, Falcão APST, Lima BRDA, et al. Análise do desempenho motor associado ao estado nutricional de idosos cadastrados no programa saúde da família, no município de Vitória de Santo Antão-PE. Ciênc Saúde Coletiva. 2012;17(5)1297-1304.

33. Moreira PL, Correa CR, Corrente JE, Martins LC, Boas PJ, Ferreira AL. Anthropometric , functional capacity, and oxidative stress changes in Brazilian community-living elderly subjects. A longitudinal study. Arch Gerontol Geriatr. 2016;66:140-6. 